\title{
Miha Pintarič
}

\section{Znanost, zgodovina, napredek: mit kot zgodba - času, ujeta med večnost in neskončnost}

Ključne besede: zgodovina, napredek, mit, čas, večnost, neskončnost, znanost

Miti, bajke in pravljice, ki se pogosto znajdejo v istem košu, naj bi se od resničnosti ločili po svoji »izmišljenosti«, čeprav si je tako mit kakor resničnost izmislil človek. $\mathrm{Na}$ tem stereotipnem razlikovanju pa vendarle nekaj je, kajti mit resničnost ponazarja in obenem povzema njeno bistvo, resnico. V mitu kot vehiculumu resnice naj bi »resničnost« iskali zgolj umsko nedorasli ljudje. Mit, prav kakor znanost, objektivizira in poenoti pogled na svet oziroma njegovo razlago. $\mathrm{V}$ obeh primerih gre za socializacijska očala, ki jih še slepemu nebogljencu nataknejo na nos, da bi videl čim bolj podobno drugim. Kakor nam namreč predložna zveza »resnica o ...« zapira polje diskurza, tako ga »znanost o ...« oziroma »mit o ...« navidezno odpirata, saj gre vendar za zgodbi, kamor naj bi vsakdo lahko dopisal svojo besedo, kar pa je v praksi iz »objektivnih« razlogov, seveda, nemogoče. Pripovedujemo, kar smo naučeni, lahko tudi zelo dobro, a le redki sami kaj dodajo. Kako pogosto je to, kar dodajo, tudi kaj vredno, pa si lahko mislimo. Nebo severne poloble je na primer polno zgodb in je poseljeno $\mathrm{z}$ bitji vseh vrst. Primerjajmo ga $\mathrm{z}$ južnim nebom, ki pozna samo črke in številke. Ja, te smo dodali mi, ki smo na poti od antike izgubili ves občutek za lepo.

»Kaj pa je resnica?« je vprašal Pilat (Jn 18, 38) in za njim še toliko drugih. Resnica ga ni zanimala, motilo ga je, da se je nekdo vtaknil v obstoječo interpretacijo resničnosti, resda ne $\mathrm{v}$ njegovo, ampak v tisto, ki je veljala za edino zveličavno $\mathrm{v}$ njegovem kolonialnem okolju. Mit, kakor pozneje znanost, je stvar reda v družbi, ki temelji na prepričljivosti enega ali druge in ki je bil s tem načet. Čas se je iz krožnega odprl v linearnega, večnemu vračanju istega, značilnem za mitsko pojmovanje, so bile porezane korenine, mi pa smo dobili zgodovino in napredek.

Prva je judovskega izvora in je trouvaille novega časa, saj temelji na kategoriji novega in njegovem vrednotenju. Herodot in Tukidid sta sicer poznala linearni, zgodovinski čas in zametek ideje napredka (tako nekako, a manj tendenciozno, kot bo srednji vek uporabljal pojem translatio - Chrétien, 1997, 291-292, vv. 1-44), saj je pred grško obstajala egipčanska kultura, ki je razmišljujočemu človeku omogočila vsaj elementarno pojmovanje diahronije. Ne glede na to temeljna grška izkušnja časa 
ni linearna, temveč krožna, podprta z mitom in s filozofijo, logiko, ki je ena in povsod enaka, torej statična in nespremenljiva.

Zgodovina judovskega ljudstva je postala zgodba vsakega posamičnega kristjana, ki se je v poznem srednjem veku pod vplivom novih duhovnih gibanj (devotio moderna) odločil hoditi za Kristusom. ${ }^{1}$ Njihovi začetki vendarle segajo vsaj v 13. stoletje, na primer v leto 1215 , ko je četrti lateranski koncil zapovedal obvezno spoved enkrat na leto, ob tem pa premaknil težišče s penitenciarijev in kodificirane pokore na nujnost izkušnje oziroma zavedanja lastne grešnosti, čemur naj bi sledila skrušenost, prvi korak na poti k boljšemu, novemu človeku. Tedanja literatura je polna solz, ki so veljale za zunanji znak iskrenosti tistega, kar se je dogajalo v človeku (prim. Perceval ali zgodba o gralu; Le Chevalier au barisel). Res pa ima vsaka pot stranpoti, tudi v tem primeru jih ni manjkalo, flagelantstvo je bila verjetno že ena takšnih.

Od črke $\mathrm{k}$ duhu ... potem ponovno od duha $\mathrm{k}$ črki. Protestantizem, naslednik poznosrednjeveških duhovnih gibanj, je s poudarkom na človeški nezadostnosti in grešnosti še globlje in bolj boleče zarezal v religiozne občutke vernika in ga tako rekoč postavil pred zaprta vrata duše. Človek je storil edino, kar je lahko, ta vrata je odprl navzven. Katoličani so osvajali Ameriko zaradi zlata, protestanti pa iz misijonarske gorečnosti (razen kadar so jih nagnali tja). Mappamundi je predvsem s svojimi belimi lisami vsakemu pravemu puritancu ali metodistu predstavljala moralno obvezo in klic. Toda noben sestop v prostor ne ostane brez posledic (Weber, 2002; Roper, 1991; Lestringant, 1990).

Pojem napredka je vse prej kot jasen v svojih nastankih, še toliko manj je jasen v svoji današnji aktualizaciji. Beseda »napredek« se, vsaj v francoščini (»progrès«), prvič pojavi v Rabelaisovi Tretji knjigi, vendar je pred Montaignem nihče ne uporablja v modernem smislu "postopnega spreminjanja na bolje«, četudi je pojem napredka prav pri Rabelaisu prisoten že v prvi knjigi, na primer v znamenitem osmem poglavju, ki vsebuje Gargantuovo pismo sinu Pantagruelu (od druge naprej pa nekoliko manj) (Harf-Lancner, 2003). Vsekakor gre za mit, vendar nov, naš, kajti antika in srednji vek ga nista poznala. Antika tako ali tako ni verjela v možnost kakršnegakoli napredka, niti osebnega niti občega, o čemer pričajo tako Nikomahova etika kakor stoiška in epikurejska modrost, kot ju, na primer, podaja Ciceron v svojem delu De finibus. Moderni mit napredka je vreden nasledek grškojudovskega paradoksa. Napredek, samoumeven in samoreferenčen, logičen, torej v svojem načelu brezpriziven, statičen in nespremenljiv, je pojmovan mitsko, kljub temu da izraža dinamično stvarnost.

1 Poleg Hoje za Kristusom in morda zbranih del H. Seuseja ali katerega drugega izmed renskih mistikov, mojster Eckhart je še najmanj značilen, velja vzeti v roke avtorje, kot so A. Tenenti, J. Delumeau in J.-Cl. Margolin, ki so se obširno ukvarjali s to in sorodnimi temami. 
Res je, da običajno uporabljamo izraze, kot sta »koncept « in »ideja « napredka, res je tudi, da napredka nikoli niso povezovali s kakšnimi alegoričnimi ponazoritvami, ki naj bi jih morda jemali dobesedno, niti ne gre pri njem za kakršnokoli retoričnonarativno kontekstualizacijo. Nima zgodbe, kot jo imajo miti. Zgodba je namreč sam. Zgodba, ki se sproti ustvarja, čeprav jo menda že vsi poznamo, ker naj bi bila v najboljšem primeru celo predvidljiva, v kar pa smo vedno manj prepričani. Pred leti je bilo govora o »koncu zgodovine«, verjetno ne po naključju prav okrog leta 2000. Toda konec ni bilo zgodovine, kvečjemu mita o zgodovini kot napredku, še posebej neomejenem in samoumevnem, zgodovina pa se, ko se je mit končal, lahko šele začne.

Vendar človek ne živi samo od zgodovine in od zgodovine še posebej ne. Hoče kačo, ki si grize rep, večnost, globoko, globoko večnost, "Ewigkeit«, kar vsebuje dimenzijo neskončnosti. Toda večnost ni nujno »neskončnost«, lahko je izkušnja odsotnosti časne razsežnosti, na primer stanje mistične zavesti. Ta je fenomenološko poganska, v aplikaciji pa krščanska, s tem da so cerkvene oblasti vedno zelo nezaupljivo gledale na »mistike«. Krščanstvo je namreč po judovstvu končna pot, ki vodi v neskončnost. Večnost brez neskončnosti je minljiva, neskončnost brez občutka odsotnosti časa pa peklenska. Zato smo celo na najbanalnejši trenutek v zgodovini, ki se vsak hip rojeva in umira, pripravljeni obesiti mit. Na trenutek, tako da $\mathrm{z}$ njim zaobjamemo še vse druge, pretekle in tiste, ki morda še bodo, s tem pa si ustvarimo figuro večnosti, ki je ne moremo izkusiti.

V krščanstvu, ki temelji na linearnem času, je bilo z miti težko. Nekaterim je preskok vendarle uspel, predvsem tistim, ki so imeli kristološki potencial, kakor je bil Herkulov (Ronsard, 1973, 207-223; Lazard, 1984), medtem ko je bilo, na primer, Prometejevemu mitu bistveno težje pripisovati podobno enoznačnost (Trousson, 2001; Duchemin, 2000). ${ }^{2}$ Drugim mitom je preskok uspel krščanstvu navkljub, ker so bili močno zasidrani v izročilu ali ker so se pač prilegali »novim«idejam.

Tako je srednji vek rad uporabljal podobo Fortune, pri kateri sicer ni mitoloških elementov, toda že v 12. stoletju, pozneje pa še bolj, Fortuna funkcionalno deluje kot poosebljenje časa (Zgodba o gralu; François Villon), in to kljub dejstvu, da je njen glavni atribut kolo, saj te prav to s prestola vrže v blato in se vrti naprej, ti pa ostaneš tam, kamor si padel. Cikličnost je nadosebna, za posameznika pa velja linearni čas. Fortuna je spojena $\mathrm{z}$ enim temeljnih antičnih mitov, saj v resnici brez usmiljenja žre svoje otroke kakor Kronos. Pri Fortuni gre obenem za didaktično-pastoralno (v teološkem, ne v literarno-ekološkem smislu) in estetsko uporabnost. Renesansa, na primer, je tako od Herkula kakor od Prometeja raje imela Merkurja, zlato, trgovino,

2 Tudi Ronsard sam je dvoumen, saj Prometeja, stvaritelja človeka (!), bodisi potiska v vlogo krivca za njegovo mizerijo bodisi mu priznava določeno veličino, ki od njega prehaja na človeški rod. 
dinamiko in seveda slavo, s katero je računala ujeti čas, ki ga še ni bilo, bil pa naj bi v tisti hipotetični prihodnosti, ki obstaja zgolj kakor upanje ali strah v človeški zavesti (Ronsard, 1973, 265-274; Lazard, 1984).

Prihodnosti ni oziroma je drugje in je drugačna. Avguštinu je to postalo tako jasno, da se je z zemeljskim odtlej ubadal samo še v luči večnosti. Iskati zemeljsko na zemlji ga ni zanimalo in edina slava, za katero se je zmenil, je bila nebeška. No, renesančniki in humanisti niso imeli njegove vere, četudi je resnici na ljubo treba poudariti, da jih je bila večina tako ali drugače globoko vernih, med seboj pa so se obkladali z zmerljivkami, kot je na primer »ateist «, kar v 16. stoletju še ni pomenilo brezbožneža, temveč nekoga, ki ne verjame v pravega Boga, oziroma vanj ne verjame na "pravilen način« (Febvre, 1984). Pravi ateisti vzniknejo v 17. stoletju. Šele tedaj začne $\mathrm{v}$ intelektualni zavesti pojavno postopoma prevladovati nad pojmovnim, kar se sicer nakazuje pri Montaignu, vendar so polno udejanjenje tega obrata šele znameniti francoski razsvetljenci, ki so vse prej kakor pristni »filozofi« v tradicionalnem, sholastičnem pomenu besede. Za te »enciklopediste «, "znanstvenike« in »intelektualne špekulante«, oziroma kar bi jim še lahko obesili takšnih imen, je značilno prav to, da nimajo več smisla za mitsko ali kakršnokoli njej sorodno obliko konfabulacije, ki bi per analogiam sporočala in razodevala globlje in na prvi pogled nevidne skrivnosti. Zanimata jih znanost in zgodovina, ena in druga, skupaj ali vsaka zase pa tvorita zgodbo, ki te pionirje moderne zavesti tako prevzame, da njenih mitskih značilnosti in resnično mitoloških razsežnosti sploh ne opazijo. Verjetno zato, ker gre v tem primeru prvič za zgodbo, ki jo človek zase in za sočloveka brez sprenevedanja piše oziroma pripoveduje sam, sam pa je v njej tudi glavni in edini junak. Bogovi so ostali nekje v meglicah Olimpa, njihove prepoznavno mitske zgodbe so izgubile družbeno funkcionalnost (ne pa tudi didaktične, estetske, historične in podobno) in se znašle na zaprašenem podstrešju mehanizmov človeške duše.

Jezik renesanse in jezik razsvetljenstva sta si v mnogočem podobna, njuna terminologija je na marsikaterem mestu formalno identična, vendar je prav $\mathrm{v}$ takšnih primerih vedno docela nasprotno pomenska. Kadar Erazem, na primer, piše o luči in svetlobi, ima v mislih božje razsvetljenje, illuminatio, nepogrešljivo na poti spoznave oziroma odločitve za takšno ali drugačno dejanje. Enaka beseda izpod peresa razsvetljenskega »filozofa« pomeni zgolj luč človeškega razuma, ki sicer ni apriorna negacija božjega razsvetljenja, toda to »filozofa " ne zanima, on se ustavi tam, kamor pade poslednji žarek človeškega. Prometejev ogenj šele tu resnično pride do izraza in paradoksalno je dejstvo, da je od tega ukradenega ognja razuma imelo največ prav obdobje, ki se je nanj najmanj sklicevalo - romantika. To pa je že naša zgodba. 


\section{Literatura}

Chrétien de Troyes, Le conte du Graal ou le Roman de Perceval, "Lettres gothiques«, Pariz 1990.

Chrétien de Troyes, Cligès, »Lettres gothiques«, Pariz 1997.

Duchemin, J., Prométhée. Histoire du Mythe, Pariz 2000.

Febvre, L., Au cour religieux du XVI siècle, Pariz 1984.

Harf-Lancner, L., L'idée de progrès dans l'Occident médiéval: un paradoxe?, v: Progrès, réaction, décadence dans l'Occident médiéval (ur. Baumgartner, E., Harf-Lancner, L.), Ženeva 2003, str. 7-22.

Lazard, M. (ur.), Autour des Hymnes de Ronsard, Pariz 1984.

Lecoy, F., Le Chevalier au barisel. Conte pieux du XIII siècle, „Classiques français du Moyen âge«, Pariz 1984.

Lestringant, F., Le huguenot et le sauvage: L'Amerique et la controverse coloniale en France, au temps des guerres de religion (1555-1589), Pariz 1990.

Lestringant, F., Mapping the Renaissance World: The Geographical Imagination in the Age of Discovery, Los Angeles 1994.

Ronsard, P. de, »Hercule chrestien«, v: Euvres complètes (ur. Laumonnier, P., Silver, I., Lebègue, R.), Pariz 1973.

Ronsard, P. de, »Hymne de Mercure«, v: Euvres complètes, (ur. Laumonnier, P., Silver, I., Lebègue, R.), Pariz 1973.

Roper, T. H., The Crisis of the Seventeenth Century: Religion, the Reformation and Social Change, Indianapolis [1967] 2001.

Suso, H., Euvres, franc. prev. J. Ancelet-Hustache, v: »Les Maîtres de la spiritualité chrétienne«, Vignes 1943.

Trousson, R., Le thème de Prométhée dans la littérature européenne, Ženeva [1964] 2001.

Weber, M., Protestantska etika in duh kapitalizma, Ljubljana 2002. 
Miha Pintarič

\section{Science, History, Progress: Myth as a Story about Time Caught between Eternity and Infinity}

Keywords: history, progress, myth, time, eternity, infinity, science

The function of myth, just like that of science, is to achieve a uniform picture of the world in the human mind. Myth, however, is based on supposed truth, not reality. Rather than a beginning, it is the end of any possible discussion. The article, based on French mediaeval and renaissance literature, introduces a view on how Western consciousness wrestled itself out of myth and into history. 